\title{
Pandemic Impacts on Florida Farmworkers: Emerging Takeaways to Inform Outreach and Policymaking'
}

\author{
Colby Silvert, Whitney A. Stone, John M. Diaz, and LaToya J. O'Neal ${ }^{2}$
}

\section{Introduction}

While the food supply chain relies on the tasks farmworkers perform to provide food for American families (Arcury \& Quandt, 2007; Koreishi, 2010), the 2019 coronavirus disease (COVID-19) pandemic has revealed new and existing health, social, and economic disparities faced by the United States (US) farmworker population. Expectedly, when society halted activities and locked down in 2020, farmworkers were quickly declared "essential workers" who should maintain their normal work duties (Xiuhtecutli \& Shattuck, 2021), placing the already vulnerable farmworker population at an increased risk for health issues (Flocks, 2020; Handal et al., 2020). As we have seen for many other health-vulnerable groups, the pandemic has emphasized how decades of social and economic marginalization and under-valorization of farmworkers continue today and have consequences. This publication aims to synthesize emerging takeaways from reporting and literature on the challenges experienced by US farmworkers during the COVID-19 pandemic, highlighting examples from Florida, when possible. Extension and outreach practitioners and policymakers are the target audience for application of the publication's findings and recommendations.

\section{What COVID-19 Has Taught Us about Farmworker Challenges}

We synthesized key insights from research, media reporting, public data, and interview sources to understand farmworkers' daily challenges amidst the COVID-19 pandemic. We discuss both new challenges for farmworkers directly linked to COVID-19 and ways in which historic inequities and disparities have manifested and affected farmworkers during the pandemic.

Unavoidable exposure and working conditions: A Purdue (2020) model estimated farmworkers to be approximately twice as likely as the overall population to contract COVID-19. Well before the pandemic, farmworkers were often pushed to work long hours under grueling conditions (Parra-Cardona et al., 2006), which has historically placed the group at an increased risk for heat-related illness and health issues (Mutic et al., 2018). In addition to farmworkers being expected to continue working throughout the pandemic, the agricultural industry's concentration on labor-intensive horticultural production (e.g., fresh fruits and vegetables) makes physical distancing extremely difficult, especially with a lack of protective equipment such as

1. This document is AEC741, one of a series of the Department of Agricultural Education and Communication, UF/IFAS Extension. Original publication date December 2021. Visit the EDIS website at https://edis.ifas.ufl.edu for the currently supported version of this publication.

2. Colby Silvert, graduate assistant; Whitney A. Stone, graduate assistant; John M. Diaz, assistant professor and Extension specialist, program development and evaluation, Department of Agricultural Education and Communication, UF/IFAS Gulf Coast REC, Plant City; and LaToya J. O'Neal, assistant professor and health and wellness Extension specialist, Department of Family, Youth and Community Sciences; UF/IFAS Extension, Gainesville, FL 32611.

The Institute of Food and Agricultural Sciences (IFAS) is an Equal Opportunity Institution authorized to provide research, educational information and other services

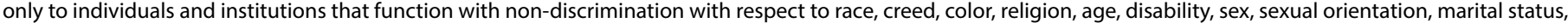

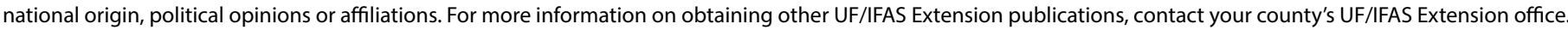
U.S. Department of Agriculture, UF/IFAS Extension Service, University of Florida, IFAS, Florida A \& M University Cooperative Extension Program, and Boards of County Commissioners Cooperating. Andra Johnson, dean for UF/IFAS Extension. 
masks (Xiuhtecutli \& Shattuck, 2021). Farmworkers are also commonly excluded from the social and labor protections most Americans can enjoy, which may exacerbate grueling working and living conditions (Handal et al., 2020). Furthermore, many farmworkers are paid a piece rate (i.e., paid according to the amount harvested), without paid benefits such as sick leave, which increases the pressure to not miss work for health reasons such as a positive COVID-19 test result or exposure (Mutic et al., 2018).

Unavoidable exposure from housing and transportation: Even outside of the workplace, economic conditions and inadequate infrastructure increase the risk of disease spread. Farmworker housing is often cramped with bunk beds, shared bathrooms, and kitchens used by over a dozen farmworkers. Furthermore, transportation to and from work sites is commonly provided in packed buses or shared vehicles (Xiuhtecutli \& Shattuck, 2021). These conditions not only increase the risk of disease transmission but also make isolation and containment of outbreaks very challenging.

Lack of access to testing and medical care: Testing and monitoring COVID-19 among farmworkers has been inconsistent and fallen short on multiple fronts. Reporting indicated some growers attempted to obscure US farm disease rates by excluding workers from testing (Reiley \& Reinhard, 2020). Testing was not required by Florida's state and local authorities, and even if farmworkers were tested, following up with them posed significant challenges for tracing (Lauzardo et al., 2021). Additionally, many farmworker communities lacked internet connectivity, which disconnected them from telemedicine resources and emotional support during this crisis (Lee et al., 2020). In Collier County, Florida, where Immokalee's tomato fields are located, the county officials opted against participating in the State's testing program (Perdomo, 2020). Fundamentally, farmworkers' lack of social protections, fear of deportation, and economic status have likely been significant hindrances to testing and seeking medical care: "Testing and social distancing guidelines may help prevent illness but cannot prevent job loss. Personal protection is no substitute for social protections" (Fawcett \& Gupta, 2020, p. 1). Complicating this constrained access to medical care is the lack of translation services and cultural awareness by some healthcare providers (Flocks et al., 2018; Herbst \& Gonzalez-Guarda, 2018).

Immigration status and fear: The agricultural workforce in the United States is predominantly comprised of Latinx workers, with half estimated by the US Department of Labor (2018) to be undocumented. Some US farmworkers' fear of deportation and removal from their jobs discourages them from speaking out against inadequate conditions or treatment by employers (González, 2019). This, along with little time afforded away from work, may deter farmworkers' pursuit of medical assistance and public services. Additionally, many farmworkers may not hold Social Security numbers, which would be required to access federal safety net programs and pandemic stimulus and aid (Onel et al., 2020). A significant number of farmworkers are also registered as $\mathrm{H}-2 \mathrm{~A}$ guestworkers, and according to Unseld (2020), COVID-19 has added to already challenging circumstances for $\mathrm{H}-2 \mathrm{~A}$ farmworkers, who are frequently transported in large groups via buses and housed closely together in barracks or hotels, where social distancing is nearly impossible. Unsurprisingly, Unseld claims that some of the worst virus outbreaks have been among $\mathrm{H}-2 \mathrm{~A}$ workers.

Political and social blame and marginalization: Before COVID-19, farmworkers long faced social barriers related to language, culture, and educational access. This marginalization has only increased in the pandemic amid the current immigration discourse. Moreover, influential politicians' anti-immigrant rhetoric and attacks against immigrants, minorities, and refugees have fueled hostility and even hate crimes against farmworkers (Medel-Herrero et al., 2021). The public discourse often promotes a narrative that farmworker communities are a burden to the American economy (e.g., "farmworkers take away jobs"), obscuring farmworkers' actual economic contributions (Areguin et al., 2020).

\section{How to Make Change: Actions to Reframe and Strengthen Support for Farmworkers}

The following recommendations are based on the findings presented above and existing examples, especially in Florida, to better provide support and protection for farmworkers.

- Make farmworkers visible: Extension and outreach professionals and others in communication and policy positions should work to shift public perceptions toward recognizing the invaluable role that farmworkers play in the US food system and society. Efforts are needed to combat political and discriminatory rhetoric to build respect and empathy rather than "othering" and blaming. Relatedly, Piccinni (2020) encouraged public officials to formally acknowledge migrant workers' contributions to society, especially during the pandemic, and promote an 
"in-this-together" narrative to build social cohesion and inclusion (p. 1).

\section{- Support and build on existing efforts where possible:}

For example, the Farm Worker Association of Florida has been mobilizing support since the 1970s among farmworkers, activists, and others from the public, private, and nonprofit sectors to improve conditions, benefits, and policies that impact farmworkers. An advantage of collaborating with these established groups is the trust and relationships they may already have built with Florida farmworkers. These groups have organized COVID-19 testing and vaccination sites that assist with delivering culturally sensitive and responsive information and language translation. UF/IFAS Extension has also increased efforts tailored to support farmworkers through the establishment of the Coalition of Florida Extension Educators, or CAFE Latino, described as "a grassroots organization with the goal to create science-based educational materials for the benefit of Spanish-speaking communities" (UF at Work, 2021, p. 1). CAFE Latino aims to push the boundaries of Extension beyond traditional white, English-speaking communities by translating content and partnering with local organizations to better meet the needs of Hispanic and Latino clientele in Florida (UF at Work, 2021).

\section{- Increase farmworkers' awareness of rights and benefits:} Farmworkers are extremely busy with taxing work schedules. Furthermore, farm managers and contractors may not fully inform farmworkers of their legal rights and opportunities, such as COVID-19 stimulus and aid, in all the necessary languages. Furthermore, resources may need to be made accessible at various literacy levels. Hence, practitioners can help disseminate sound knowledge for farmworkers (specific to their legal status and situations) and support to navigate different systems and access assistance. Rodriguez et al. (2018) suggested that practitioners leverage mobile learning platforms, when possible, using smartphones, tablets, or other devices, to deliver language-appropriate health and safety information and trainings to farmworkers in remote work environments.

- Come up with systemic solutions: A key aim of this article was to illustrate that although the pandemic has exacerbated injustices and inequities faced by farmworkers, these challenges have been decades in the making. Thus, quick, easy fixes will have little impact for entrenched and complex issues. We call for systems change approaches that address multiple levels of the system that constrain and burden farmworkers (Kania et al., 2018). Namely, evidence suggests practitioners should consider the policy environment level (including the social safety net), the public discourse and perception level, and the individual farmworker level (e.g., individuals' capacities and access to information and resources) when designing and evaluating interventions.

\section{Conclusion}

The COVID-19 pandemic magnified issues for US farmworkers that stem from multiple decades of neglect, invisibility to consumers, and systemic oppression, which created preconditions for farmworkers to disproportionately suffer. As Xiuhtecutli and Shattuck (2021) explain, "the social and spatial inequalities that have always put farmworkers at risk are the same conditions that have allowed COVID-19 to devastate farmworker communities" (p. 75). Given the challenges and opportunities discussed, specific needs exist to explore multifaceted systemic solutions, build on and strengthen existing efforts in Florida and beyond, and positively shift public perception and awareness.

\section{References}

Arcury, T. A., \& Quandt, S. A. (2007). Delivery of health services to migrant and seasonal farmworkers. Annual Review of Public Health, 28, 345-363. https://doi.org/10.1146/ annurev.publhealth.27.021405.102106

Areguin, M. A., Huynh, Q., \& Berzenski, S. R. (2020). Reaping more than what they sow: A critical race perspective on environmental microaggressions toward Latinx farmworkers. Social Psychological and Personality Science, 11(7), 938-948. https://doi.org/10.1177/1948550620919565

Fawcett, M., \& Gupta, A. (2020, June 19). Undocumented farmworkers are refusing COVID tests for fear of losing their jobs. In These Times. http://inthesetimes.com/working/entry/22608/ undocumented_farmworkers_are_refusing_covid_tests_for_fear_of_losing_jobs

Flocks, J. (2020). The potential impact of COVID-19 on H-2A agricultural workers. Journal of Agromedicine, 25(4), 367-369. https://doi.org/10.1080/1059924X.2020.1814922.

Flocks, J., Tovar, J. A., Economos, E., Mac, V. V. T., Mutic, A., Peterman, K., \& McCauley, L. (2018). Lessons learned from data collection as health screening in underserved farmworker communities. Progress in Community Health Partnerships: Research, Education, and Action, 12(1), 93-100. https://doi.org/10.1353/cpr.2018.0024 
González, E. (2019, June 6). Migrant farm workers: Our Nation's invisible population. Diversity, Equity and Inclusion Community of Practice. https://copdei.extension.org/ migrant-farm-workers-our-nations-invisible-population/

Handal, A. J., Iglesias-Ríos, L., Fleming, P. J., ValentínCortés, M. A., \& O’Neill, M. S. (2020). "Essential" but expendable: Farmworkers during the COVID-19 pandemic-The Michigan Farmworker Project. American Journal of Public Health, 110(12), 1760-1762. https://doi. org/10.2105/AJPH.2020.305947

Herbst, R. B., \& Gonzalez-Guarda, R. (2018). Exploring perspectives of well-being in Latina/o migrant workers. Counseling Psychology Quarterly, 31(2), 137-161. https:// doi.org/10.1080/09515070.2016.1243516

Kania, J., Kramer, M., \& Senge, P. (2018). The water of systems change. FSG. https://www.fsg.org/publications/ water_of_systems_change

Koreishi, S., \& Donohoe, M. T. (2010). Historical and contemporary factors contributing to the plight of migrant farmworkers in the United States. Social Medicine, 5(1), 64-73. https://socialmedicine.info/index.php/ socialmedicine/article/viewFile/343/1041

Lauzardo, M., Kovacevich, N., Dennis, A., Myers, P., Flocks, J., \& Morris, G. (2021). An outbreak of COVID-19 among H-2A temporary agricultural workers. American Journal of Public Health, 111, 571-573. https://doi.org/10.2105/ AJPH.2020.306082

Lee, J. G. L., LePrevost, C. E., Harwell, E. L., Bloss, J. E., Cofie, L. E., Wiggins, M. F., \& Firnhaber, G. C. (2020). Coronavirus pandemic highlights critical gaps in rural Internet access for migrant and seasonal farmworkers: A call for partnership with medical libraries. Journal of Medical Library Association, 108(4), 651-655. http://dx.doi. org/10.5195/jmla.2020.1045

Medel-Herrero, A., Torreiro-Casal, M., Hovey, J. D., Rascon-Garcia, K., Smiley-Jewell, S., \& Shumway, M. (2021). The increasing toll of racism and discrimination on California agricultural workers and their families under the Trump administration. Ethnicities, 21(4), 638-663. https:// doi.org/10.1177/14687968211018255
Mutic, A. D., Mix, J. M., Elon, L., Mutic, N. J., Economos, J., Flocks, J., ... McCauley, L. A. (2018). Classification of heat-related illness symptoms among Florida farmworkers. Journal of Nursing Scholarship, 50(1), 74-82. https://doi. org/10.1111/jnu.12355

Onel, G., Simnitt, S., Stacciarini, J. M., \& Tovar-Aguilar, A. (2020). COVID-19 risk factors vary by legal status among Florida crop workers. Choices, 35(3). https://ageconsearch. umn.edu/record/305278/files/cmsarticle_749.pdf

Parra-Cardona, J. R., Bulock, L. A., Imig, D. R., Villarruel, F. A., \& Gold, S. J. (2006). “Trabajando duro todos los días": Learning from the life experiences of Mexican-origin migrant families. Family Relations, 55(3), 361-375. https:// doi.org/10.1111/j.1741-3729.2006.00409.x

Perdomo, A. (2020, October 8). Collier County will not participate in FL Ag Dept's COVID-19 test efforts for farm workers. WGCU and Health News Florida. https://health. wusf.usf.edu/health-news-florida/2020-10-08/colliercounty-will-not-participate-in-fl-ag-depts-covid-19-testefforts-for-farm-workers

Piccinni, A. (2020, June 9). Local narratives on migrant integration: Cities' strategies could gain momentum after COVID. The Chicago Council on Global Affairs. https:// www.thechicagocouncil.org/commentary-and-analysis/ blogs/local-narratives-migrant-integration-cities-strategiescould-gain

Purdue University. (2020). Purdue food and agriculture vulnerability index. https://ag.purdue. edu/agecon/Pages/FoodandAgVulnerabilityIndex. aspx?_ga=2.49471334.1159720487.1600111458250602208.1598985334

Reiley, L., \& Reinhard, B. (2020, September 24). Virus's unseen hot zone: The American farm. The Washington Post. https://www.washingtonpost.com/business/2020/09/24/ seasonal-farm-workers-coronavirus/

Rodriguez, A., Hagevoort, G. R., Leal, D., Pompeii, L., \& Douphrate, D. I. (2018). Using mobile technology to increase safety awareness among dairy workers in the United States. Journal of Agromedicine, 23(4), 315-326. https://doi.org/10.1080/1059924X.2018.1502704 
UF at Work. (2021, October 13). Bridging the gap between UF and Spanish-speaking communities throughout Florida. https://news.hr.ufl.edu/spotlight/bridging-thegap-between-uf-and-spanish-speaking-communitiesthroughout-florida/

Unseld, M. (2020). Farmworkers-Always essential, always at risk: An interview with Jeannie Economos. NEW SOLUTIONS: A Journal of Environmental and Occupational Health Policy, 30(4), 305-310. https://doi. org/10.1177\%2F1048291120970524

US Department of Labor. (2018). Findings from the National Agricultural Workers Survey 2015-2016: A demographic and employment profile of United States farmworkers (Research Report 13). https://www.doleta.gov/naws/research/docs/ NAWS_Research_Report_13.pdf

Xiuhtecutli, N., \& Shattuck, A. (2021). Crisis politics and US farm labor: Health justice and Florida farmworkers amid a pandemic. The Journal of Peasant Studies, 48(1), 73-98. https://doi.org/10.1080/03066150.2020.1856089 